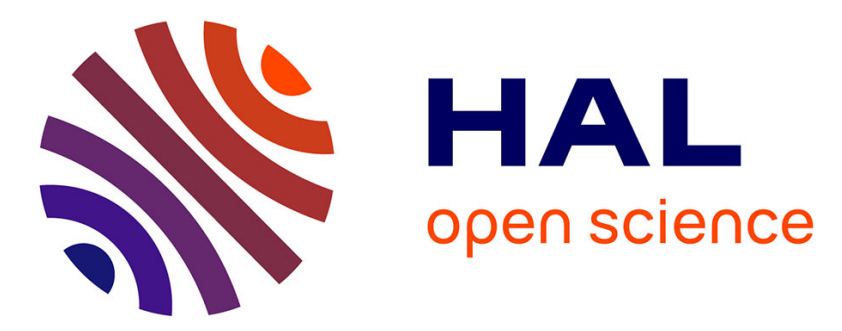

\title{
Greenhouse gas emissions from Spanish motorway transport: Key aspects and mitigation solutions
}

Paula Perez-Lopez, Carles M. Gasol, Jordi Oliver-Sola, Sagrario Huelin, Maria Teresa Moreira, Gumersindo Feijoo

\section{- To cite this version: \\ Paula Perez-Lopez, Carles M. Gasol, Jordi Oliver-Sola, Sagrario Huelin, Maria Teresa Moreira, et al.. Greenhouse gas emissions from Spanish motorway transport: Key aspects and mitigation solutions. Energy Policy, 2013, 60, pp.705-713. 10.1016/j.enpol.2013.04.075 . hal-01284765}

\section{HAL Id: hal-01284765 https://hal.science/hal-01284765}

Submitted on 16 Dec 2016

HAL is a multi-disciplinary open access archive for the deposit and dissemination of scientific research documents, whether they are published or not. The documents may come from teaching and research institutions in France or abroad, or from public or private research centers.
L'archive ouverte pluridisciplinaire HAL, est destinée au dépôt et à la diffusion de documents scientifiques de niveau recherche, publiés ou non, émanant des établissements d'enseignement et de recherche français ou étrangers, des laboratoires publics ou privés. 


\section{Greenhouse gas emissions from Spanish motorway}

\section{transport: Key aspects and mitigation solutions}

Paula Pérez-López ${ }^{1, *}$, Carles M. Gasol ${ }^{2,3}$, Jordi Oliver-Solà ${ }^{2,3}$, Sagrario Huelin ${ }^{4}, \mathrm{M}^{\mathrm{a}}$ Teresa Moreira $^{1}$ and Gumersindo Feijoo ${ }^{1}$

1 Department of Chemical Engineering, School of Engineering, University of Santiago de Compostela. 15782 - Santiago de Compostela, Spain

2 Autonomous University of Barcelona, Institute of Environmental Science \& Technology ICTA, SosteniPrA IRTA, 08193 - Barcelona, Spain

${ }^{3}$ Inèdit Innovació SL. UAB Research Park. Carretera de Cabrils km 2 (IRTA), 08348 - Cabrils (Barcelona), Spain

${ }^{4}$ Abertis Foundation, Avenida del Parc Logístic, 12-20 (Zona Franca), 08040 Barcelona, Spain

* Corresponding author: Tel.: +34-881-816-739; Fax: +34-981-528-050; E-mail address: paula.perez@usc.es 


\begin{abstract}
The current increasing importance of road transport in the overall greenhouse gas (GHG) emissions has led to the adoption of diverse policies for the mitigation of global warming. These policies focus in two directions, depending on whether they involve the reduction of emissions or the mitigation through carbon dioxide $\left(\mathrm{CO}_{2}\right)$ sequestration. In this paper, the Tier 3 methodology from the European Monitoring and Evaluation Programme and the Environment Agency (EMEP/EEA) was applied to determine the evolution of Spanish motorway GHG emissions in the period 20052010. According to the results, though the average daily traffic (ADT) is the major parameter, the average fleet age and vehicle size also affect the level of emissions. Data analysis also revealed a clear connection between the decrease in European trade volume during the financial crisis and the GHG release, despite its temporary character. Among the three improvement scenarios evaluated, reduced speed limit seems the most direct measure while the consequences of afforestation strongly depend on the traffic density of the stretch of the motorway considered. Finally, technological improvement requires a drastic change in the fleet to obtain substantial decrease. The combination of different policies would allow a more robust strategy with lower GHG emissions.
\end{abstract}

Keywords GHG emissions, Road transport, $\mathrm{CO}_{2}$ mitigation 


\section{Introduction}

Recent scientific observations reveal that greenhouse gas (GHG) emissions from anthropogenic activities have modified their natural variability, causing an increase in their concentration levels (Crowley, 2001; Doney et al., 2006; García et al., 2010). The alteration of the energy balance has led to the environmental impact of climate change with adverse effects in ecosystem and society, evidenced even in short and medium terms (IPCC, 2007; Lindner et al., 2010; Walther et al., 2002). In order to prevent hazardous consequences and stabilize GHG concentration at an acceptable level, governments are adopting policies to slow down climate change. More than 100 countries have agreed to set a global warming limit of $2^{\circ} \mathrm{C}$, which requires a decrease in global emissions of at least half 1990 levels (Meinshausen et al., 2009; UNFCCC, 1998). However, world emissions are increasing faster than at the beginning of the 1990s, especially in developing countries (Baiocchi et al., 2010). Even more, according to the International Energy Agency (IEA, 2011), global energy-related emissions of carbon dioxide $\left(\mathrm{CO}_{2}\right)$, the main $\mathrm{GHG}$, reached a record of $30.4 \mathrm{Gt}$ in 2010 .

Energy sector is one of the main sources of GHG emissions derived from anthropogenic activities. Particularly, transport accounts for approximately $15 \%$ of overall emissions and is still increasing in most countries $(\mathrm{Li}, 2011$; OECD/ITF, 2010). In fact, this sector experienced the largest growth (+24\%) in EU-27 GHG emissions between 1990 and 2008, with more than 90\% coming from road transport; whereas total emissions were reduced to $11.1 \%$ below their 1990 level (EEA, 2011). In the case of Spain, energy-related sources in 1990 included $74.2 \%$ of the total of 283.2 $\mathrm{Mt} \mathrm{CO}_{2}$ eq emitted, with $19.5 \%$ of total emissions derived from transport. Almost two decades later, total emissions had increased $26.9 \%$ in 2009 while 
specific transport emissions had grown by $52.6 \%$ from the corresponding level in 1990, representing a final percentage of $25.7 \%$ (Spanish Ministry of the Environment and Rural and Marine Affairs, 2011).

According to Spanish Ministry of Development (2009), GHG emissions from road transport account for about $90 \%$ of total GHGs from national transport sector. Light vehicles, including passenger cars, motorcycles and light freight vehicles, contribute with $66 \%$ to the total emissions, whereas heavy-duty vehicles and coaches account for $34 \%$. With regard to driving conditions, $49.6 \%$ of road transport emissions in 2006 were generated in high-speed ways, specifically in intercity routes. In the same base year, highways and motorways represented $48.1 \%$ of the total travelled kilometers in Spain, so that the contribution per travelled kilometer is higher than in other types of road (Spanish Ministry of Development, 2012). During the last years, travelled kilometers in highways and motorways have increased, reaching $51.5 \%$ of the total road transport in 2010.

Due to the importance of transport sector, there is an urgent need to adopt improvement measures in order to limit GHG emissions. These improvements can be achieved by applying transport policies focused in two directions: i) reduction of emissions or ii) mitigation through $\mathrm{CO}_{2}$ capture or sequestration processes (Smith, 2004). Moreover, the reduction of emissions from road transport can be addressed by promoting an updating of technologies or by forcing a change in the operation of the existing vehicles. In this study, three main strategies were selected, according to the suitability of the above-mentioned policies in the Spanish context. These scenarios include forestry activities that compensate $\mathrm{CO}_{2}$ release, technological improvement of vehicles and changes in driving patterns (Barkenbus, 2010; EMEP/EEA Emission Inventory Guidebook, 2009; Hansen et al., 1995; McCarl and Sands, 2007). 
Regarding the involved stakeholders, the first option would be the only feasible one for the motorway operator, whereas the change in driving patterns through speed limitation would require the government intervention and a technological updating would constitute a more widespread measure, affecting international vehicle manufacturers and policy-makers.

The use of afforestation and reforestation as compensation options has been long discussed (Bala et al., 2007; Canadell and Raupach, 2008; Kaul et al., 2010; Malmsheimer et al., 2008; Marland and Schlamadinger, 1997). The rationale behind this strategy lies on the photosynthesis process by which plants uptake $\mathrm{CO}_{2}$ from the atmosphere. The Kyoto Protocol explicitly mentions that GHG removal by sinks resulting from direct human-induced forestry activities shall be used to meet the reduction commitments assigned to each country (UNFCCC, 1998). However, several drawbacks in the inclusion of forestry activities in the GHG inventory have been reported. In this sense, European Commission (2008) argues that the adoption of this strategy would require a standard of monitoring and reporting of emissions that is not currently available. In addition, it could delay the development of carbonefficient technologies and threat local ecosystems due to the potential use of faster growing species. Streck et al. (2009) pointed out the non-permanence of the carbon stored in biomass and soils due to disturbances, such as fires or illegal logging. Furthermore, some authors suggest that global forestation could even lead to warming due to surface albedo changes, specifically in middle and high latitudes (Betts, 2000; Bala et al., 2007). Finally, as the relative potential contribution of forest sinks will decline within the century, forest-carbon absorption should not be considered a long-term solution to global warming but a temporary alternative (Malhi et al., 2002). 
Concerning technological measures, policies shall focus on the development of alternative energy sources with lower GHG emissions or the reduction of energy use through the substitution of inefficient vehicles. Nowadays, transport is mainly dependent on non-renewable liquid fuels such as gasoline and diesel, which are linked to $40 \%$ of the total energy consumption in the world (Tan et al., 2008). In the Spanish case, these fuels were responsible of $99.8 \%$ of total GHG emissions from road transport in 2009 (Spanish Observatory for Sustainability, 2011). According to several authors, the substitution of these fuels by renewable sources such as ethanol can lead to reductions of $60-80 \%$ in GHG emissions while hydrogen fuel cell vehicles may result in an improvement of 60\% (González-García et al., 2010; Nguyen et al., 2007; Stephens-Romero et al., 2009). Another possibility is the reduction of fuel consumption through vehicle downsizing, lower power-to-weight ratios or more efficient technologies (Michaelis and Davidson, 1996; Zervas, 2010a). However, new technologies are emerging slowly in Spain, where gasoline and diesel include 99\% of national road fleet (Spanish General Directorate of Traffic - DGT -, 2012). Thus, the substitution of vehicles shall be encouraged so as to increase the number of low-consumption vehicles. Among the measures to substitute vehicles with high emissions, many studies show the effectiveness of taxing size or gasoline, as well as subsidizing new vehicles (West, 2004).

Nevertheless, fuel consumption and therefore GHG emissions depend not only on vehicle technology, but also on driving patterns. Indeed, a strong dependency between pollutant emissions and speed level has been widely reported (André and Hammarström, 2000; Ntziachristos and Samaras, 2000; Pandian et al., 2009). Regarding this effect, Sjodin et al. (1998) measured a large on-road fleet in a tunnel, showing that there was a minimum in the emissions of carbon monoxide (CO) and 
$\mathrm{CO}_{2}$ for a speed range between 60 and $80 \mathrm{~km} / \mathrm{h}$, which is in agreement with the values reported in other studies (Barth and Boriboonsomsin, 2008; El-Shawarby et al., 2005). As a result, a decrease in speed limit has been proposed as a feasible policy to reduce GHG emissions (Barkenbus, 2010).

Controlling GHG emissions from the transport sector requires an accurate computation of these gases for the evaluation of the strategies related to climate policy (Creutzig et al., 2011). Different alternatives for the quantification of GHG emissions may be used for this purpose. Weigel et al. (2010) distinguish two main categories: registry based calculators and Life Cycle Assessment calculators. Registry based calculators allow a consistent approach to end-use GHG emissions, whereas Life Cycle calculators may enable a holistic assessment of a wider system that includes the emissions associated with the production, use and disposal of fuels and vehicles. Regarding the inventoried gases, current climate policies focus on direct GHGs, whose behavior is relatively well-known. However, Fugestveldt et al. (2008) highlighted the need to take into account other mechanisms by which emissions from transport can also affect climate. Among these mechanisms, direct emissions of aerosols and indirect GHGs such as precursors of tropospheric ozone or related gases which potentially affect the oxidation capacity of the atmosphere should be considered.

The present study aims to develop a detailed assessment of GHG emissions and evaluate feasible improvement scenarios within the Spanish context. As operational emissions have been proven as the dominant contribution to GHG emissions from road transport (Chester and Horvath, 2009), the evaluation will focus on emissions which are directly generated from vehicle circulation. Therefore, a registry based calculation was applied to three model stretches. The objective is to analyze the 
evolution of emissions from motorway transport during the recent years as well as the alternatives to reduce these emissions. The selected stretches allow the evaluation of low, medium and high route lengths and traffic intensities. The Tier 3 methodology allows the quantification of 12 gases from the GHGs listed by IPCC (2007): $\mathrm{CO}_{2}, \mathrm{CO}$, methane $\left(\mathrm{CH}_{4}\right)$, nitrous oxide $\left(\mathrm{N}_{2} \mathrm{O}\right)$ and 8 non-methane volatile organic compounds (NMVOCs), including ethane, propane, butane, ethylene, propylene, toluene, acetaldehyde and acetone. The contribution of different types of vehicles was also calculated. Finally, a sensitivity analysis of three limitation measures was carried out, showing the effect of forestry mitigation, technological improvement and speed dependency on total emissions.

\section{Methodology}

\subsection{GHG emissions from road transport}

The development of the emission inventory was performed according to the methodology Tier 3 described by the European Monitoring and Evaluation Programme and the Environment Agency (EMEP/EEA Emission Inventory Guidebook, 2009). The calculation procedure combines a set of technical data, such as emission factors, and activity data, mainly average daily traffic (ADT) that gives the total vehicle-kilometers travelled (VKT) per year.

As mentioned before, emissions are strongly dependent on vehicle size and technology (Michaelis and Davidson, 1996). For this reason, the Tier 3 methodology has a specific set of equations with characteristic parameters to determine emission factors from each type of vehicle. Thus, a detailed classification of the national fleet was considered. Emissions factors and other technical data were taken from EMEP/EEA Emission Inventory Guidebook (2009), whereas the distribution of 
technologies was estimated from the national road fleet data of the Spanish General Directorate of Traffic (DGT, 2012). Annual ADT and VKT, as well as the length of the evaluated stretches, were obtained from the Ministry of Development (2012) for the period 2005-2010. This information is detailed within the Supplementary Material.

The Tier 3 approach distinguishes two types of emissions referred to engine operation. Hot emissions $\left(\mathrm{E}_{\mathrm{HOT}}\right)$ refer to the operation of the engine at its normal temperature whereas cold-start emissions ( $\mathrm{E}_{\mathrm{COLD}}$ ) occur during the transient warming-up of the engine. The algorithm also takes into account three different conditions: urban, rural and highway driving. Cold-start emissions are mainly attributed to urban and secondarily to rural conditions. The engine generally achieves hot operation before reaching the motorway, so no cold-start emissions are associated with highway driving in the applied methodology. Total emissions $\left(\mathrm{E}_{\mathrm{TOTAL}}\right)$ are calculated as the sum of cold and hot emissions from the three driving conditions. However, as the system boundaries in the present work are limited to motorway transport, total emissions corresponded to hot emissions of highway driving, as shown in eq 1 .

$$
E_{\text {TOTAL }}=E_{\text {HOT,URBAN }}+E_{\text {COLD,URBAN }}+E_{\text {HOT,RURAL }}+E_{\text {COLD, }, \widehat{U R A L}}+E_{\text {HOT,HIGHWAY }}+E_{\text {COAD, HIGHWAY }}
$$

The calculation method allowed the quantification of pollutants from three categories. The gases of the first group, namely $\mathrm{CH}_{4}, \mathrm{~N}_{2} \mathrm{O}, \mathrm{CO}$ and total volatile organic compounds (VOC), were calculated from eq 2, based on the specific emission factors for hot engine operation and highway driving.

$$
E_{H O T ; j, k}=N_{k} \cdot M_{k} \cdot e_{H O T ; j, k}
$$


where $E_{\mathrm{HOT} ; j, \mathrm{k}}$ are the total hot exhaust emissions of the pollutant $\mathrm{j}$ produced by vehicles of technology $\mathrm{k}$ driven on highways $(\mathrm{g}), \mathrm{N}_{\mathrm{k}}$ is the number of vehicles of technology $\mathrm{k}, \mathrm{M}_{\mathrm{k}}$ is the mileage per vehicle driven by vehicles of technology $\mathrm{k}(\mathrm{km})$, and $\mathrm{e}_{\mathrm{HOT} ; \mathrm{j}, \mathrm{k}}$ is the emission factor for pollutant $\mathrm{j}$ for the vehicle technology $\mathrm{k}(\mathrm{g} / \mathrm{km})$ calculated according to specific equations for each type of vehicle. The product of $\mathrm{N}_{k}$ and $\mathrm{M}_{\mathrm{k}}$ represents the total $\mathrm{VKT}$, which is the total of $\mathrm{km}$ travelled by all the vehicles of technology $\mathrm{k}$ on the road during the reference period.

Equation 3 was applied to calculate $\mathrm{CO}_{2}$ emissions, which depend on fuel consumption and specifications.

$$
E_{C O_{2} ; k, m}=44.011 \cdot \frac{F C_{k, m}}{12.011+1.008 \cdot r_{H: C, m}+16.000 \cdot r_{O: C, m}}
$$

where $\mathrm{E}_{\mathrm{CO} 2 ; \mathrm{k}, \mathrm{m}}$ are $\mathrm{CO}_{2}$ emissions produced by vehicles of technology $\mathrm{k}$ and fuel $\mathrm{m}$ $(\mathrm{g}), \mathrm{FC}_{\mathrm{k}, \mathrm{m}}$ is the fuel consumption of those vehicles, $\mathrm{r}_{\mathrm{H}: \mathrm{C}, \mathrm{m}}$ is the ratio of hydrogen $(\mathrm{H})$ to carbon $(\mathrm{C})$ for fuel $\mathrm{m}$ determined as $\mathrm{r}_{\mathrm{H}: \mathrm{C}}=11.916(\mathrm{H} / \mathrm{C})$, and $\mathrm{r}_{\mathrm{O}: \mathrm{C}, \mathrm{m}}$ is the ratio of oxygen to carbon for the same fuel calculated as $\mathrm{r}_{\mathrm{O}: \mathrm{C}}=0.7507(\mathrm{O} / \mathrm{C}) . \mathrm{FC}_{\mathrm{k}, \mathrm{m}}$ required in eq 3 is calculated in the same way as pollutants of group 1, according to eq 2 .

Finally, different NMVOCs were estimated by the use of fractions specified in EMEP/CORINAIR guide. In particular, indirect GHGs from Collins et al. (2002) were inventoried, including ethane, propane, butane, ethylene, propylene, toluene, acetaldehyde and acetone. Total GHG emissions were unified and measured in terms of Global Warming Potential (GWP), defined as the impact of human emissions on the radiative forcing of the atmosphere (Guinée et al., 2011). A 100-year time horizon was considered by applying the factors given by Forster et al. (2007). 


\section{2. $\mathrm{CO}_{2}$ storage in forest species}

The quantification of the carbon stored in biomass and $\mathrm{CO}_{2}$ uptake was based on one of the methodologies proposed by IPCC for estimating carbon stocks (IPCC, 2003). Due to the controversy over the use of forestry activities for mitigation, a conservative approach was taken and accordingly, only $\mathrm{CO}_{2}$ uptake of aboveground biomass during the build-up of forests was considered. Nevertheless, several authors estimate that only $10-30 \%$ of the carbon sequestration occurs in the forest floor and mineral soil, while the main contribution corresponds to the trees themselves (PérezCruzado et al., 2012; Richter et al., 1999). In fact, De Vries et al. (2006) reported an average ratio of 4.1 between carbon sequestration in the tree and the soil for European forests, which is even higher in the case of Southern European areas (8.9). Therefore, the quantification in the present study was underestimated in about 10$20 \%$ of the actual value. Equation 4 was applied to estimate the total carbon stored in the biomass, which depends on the geometry and species.

$$
C=V O B \cdot D \cdot B E F \cdot(1+R) \cdot C F \cdot N t
$$

where $\mathrm{C}$ is the total carbon in biomass ( $\mathrm{kg} /$ tree), $\mathrm{VOB}$ is the volume over bark of free bole $\left(\mathrm{m}^{3} /\right.$ tree $)$, D is basic wood density $\left(\mathrm{kg} / \mathrm{m}^{3}\right)$, BEF is the biomass expansion factor for conversion of VOB to aboveground tree biomass, $\mathrm{R}$ is root-to-shoot ratio, $\mathrm{CF}$ is the carbon fraction of dry matter ( $\mathrm{kg} \mathrm{C} / \mathrm{kg}$ biomass), and $\mathrm{Nt}$ is the number of trees. $\mathrm{CO}_{2}$ uptake is obtained by just multiplying the value by $44 / 12$ according to the stoichiometric rate.

VOB is the volume of the tree excluding roots and branches, that is measured from stump or buttress to crown point or first main branch (Brown, 1997). This volume was calculated according to eq 5 given by Burriel et al. (2004). 
$V O B=\pi \cdot\left(\frac{D B H}{2}\right)^{2} \cdot H \cdot K_{f}$

where $\mathrm{DBH}$ is the diameter at breast height $(1.3 \mathrm{~m})$ expressed in $\mathrm{m}, \mathrm{H}$ is the height of the tree $(\mathrm{m})$, and $\mathrm{K}_{\mathrm{f}}$ is a dimensionless shape coefficient which depends not only in the species, but also in the size of the tree.

According to the scope of the present study, a typical Spanish distribution of species was considered. The data for determining $\mathrm{CO}_{2}$ uptake by forests were obtained from IPCC (2003) and the on-line MiraBosc software (SiBosC, 2012), a tool developed by the Catalonian Centre for Ecological Research and Forestry Applications (CREAF) and the Department of Environment and Housing (DMAH).

\section{Results}

3.1. GHG emissions trends during 2005-2010

First of all, GHG emissions of road transport, derived directly from engine operation were determined for the period 2005-2010 years in three model stretches: low ADT (Sevilla-San Rafael), medium ADT (Sevilla-Cádiz) and high ADT (BarcelonaTarragona). According to Spanish road legislation, average speeds of $120 \mathrm{~km} / \mathrm{h}$ and $85 \mathrm{~km} / \mathrm{h}$ were considered, respectively for light and heavy vehicles. Figure 1 shows the tendency observed for each stretch, whose emissions were clearly dependent on the ADT and, therefore, on VKT, as expected from previous works (Marshall et al., 2005; Melania et al., 2011). Thus, a higher ADT corresponded to a larger level of emissions according to an approximately linear function. The slight deviation from this behavior mainly came from the different vehicle distributions among the analyzed years. 
Regarding the evolution during the considered period, there was a remarkable change in 2007 and 2008. In fact, two regions for both high ADT and medium ADT model stretches can be distinguished in Figure 1. The first region showed a continuous increase in emissions between 2005 and 2007, whereas the second period experienced a marked drop. This decrease led to emission reductions in 2010 of $2.0 \%$ in the case of medium ADT stretch and $13.9 \%$ in the high ADT stretch. Particularly for the low ADT stretch, GHG emissions considerably increased by $24.2 \%$ from 2005 to 2010 . The reason of this divergence with respect to the behavior observed in the other stretches could be the recent construction of the road, inaugurated in 2004, that explains the pronounced increase, specifically from 2005 to 2007. Indeed, considering 2007 as a reference year with a stabilized traffic density, the growth for the last three years was limited to $1.5 \%$.

The main explanation for the drop in GHG emissions is probably the world financial crisis that started during the analyzed period. In fact, the estimated reduction due to the downturn in economic activity ranges from 3 to $10 \%$, which points out the sharpest decrease in emissions in the past 40 years (OECD/ITF, 2010). European road transport has been especially affected by the financial crisis in the freight sector, which shrank by more than 6\% in Spain between 2008 and 2009 (Pasi, 2009). In spite of the global diminution in emissions, Peters et al. (2012) aim that the crisis has only had a temporary effect, and predict a rapid growth for emissions during the next years. 


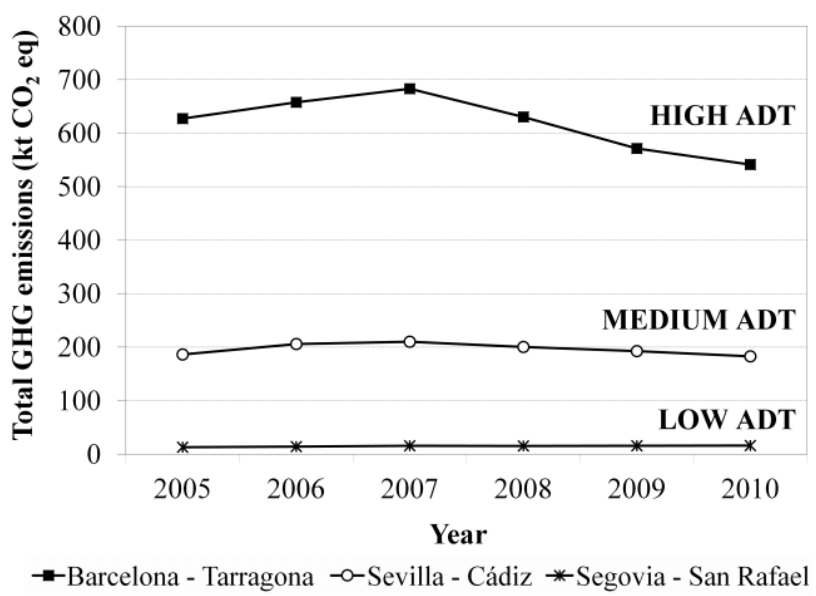

Figure 1. Evolution of total GHG emissions for three motorway stretches during 2005-2010 for average speeds of $120 \mathrm{~km} / \mathrm{h}$ and $85 \mathrm{~km} / \mathrm{h}$ for light and heavy vehicles

The different level of emissions prevents the comparison between absolute values for the three model stretches. However, Figure 2 presents a relative assessment that expresses data in terms of GHG emitted per km travelled. Available databases (EEA, 2011; EPA, 2009; UK Government, 2012a, 2012b) show that emissions of common vehicles may vary from approximately 100 to $500 \mathrm{~g} \mathrm{CO}_{2} / \mathrm{km}$. According to the results of the case study, total emissions divided by VKT ranged from 235 to $285 \mathrm{~g}$ $\mathrm{CO}_{2} \mathrm{eq} / \mathrm{km}$. The vehicle distribution is a significant parameter that influences emissions, causing divergences between the calculated values. New technologies often have a lower rate of emissions that can partially explain the decrease observed in Figure 2. However, the weight and size of the vehicles must be also taken into account (De Mol et al., 2009; Zervas, 2010b). As mentioned above, freight transport has suffered a drop due to the economic recession. Heavy-duty vehicles associated to this sector have higher average emissions per $\mathrm{km}$ than light vehicles, so the decrease in freight road transport should have contributed to the decrease of emissions since 2008 . 


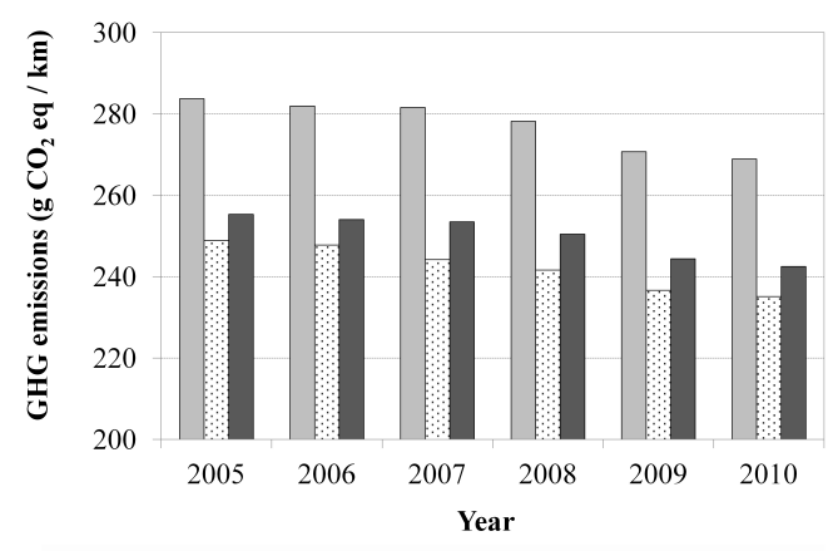

$\square$ Barcelona - Tarragona Sevilla - Cádiz $\square$ Segovia - San Rafael

Figure 2. Average GHG emissions per km travelled in each motorway stretch for average speeds of $120 \mathrm{~km} / \mathrm{h}$ and $85 \mathrm{~km} / \mathrm{h}$ for light and heavy vehicles

Despite revealing a similar evolution over the years, GHG emissions per km for the high ADT stretch (Barcelona-Tarragona) adopt values between 10 and 13\% higher than the corresponding emissions in medium and low stretches. As identical national fleet data were taken into account for the three stretches, this deviation cannot be attributed to different vehicle technologies. Figure 3 demonstrates that the ratio of light to heavy vehicles is likely to be the main reason of the discrepancy. Actually, the highest relative emissions match to the stretch with a lower amount of light vehicles. According to Figure 3a, Barcelona-Tarragona has an average percentage of 81\% light vehicles, whereas Segovia-San Rafael and Sevilla-Cádiz hold percentages of 90 and 92\%, respectively. In addition, the percentage was found to increase continuously from 2007 onwards. This behavior was coincident with the reduction observed for the emissions per $\mathrm{km}$ in Figure 2. Furthermore, Figure $3 \mathrm{~b}$ shows that light vehicles accounted for a range between $64 \%$ and $83 \%$ of the total emissions, so the unitary contribution (emissions per vehicle) was indeed substantially lower for this category than for heavy vehicles. 

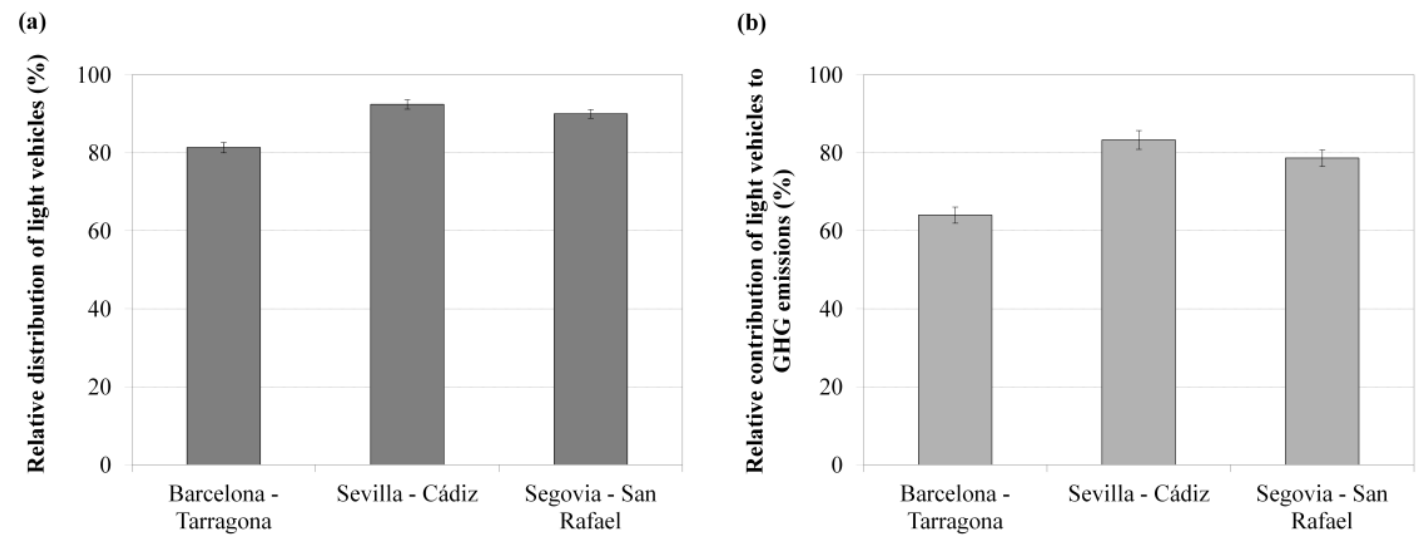

Figure 3. Percentage of light vehicles from the total fleet for each model stretch (a) and relative contribution to GHG emissions (b)

Figure 4 represents the role of all the gases affecting climate that can be measured by the Tier 3 methodology. According to the 100-year GWPs from Forster et al. (2007), $\mathrm{CO}_{2}$ is the major contributor to the total emissions, with nearly $97 \%$ of the impact. This behavior is consistent with the tendency observed for both European and American vehicles from sources such as Ecoinvent database (Spielman et al., 2007) or Davis et al. (2010). In these databases, $\mathrm{CO}_{2}$ contribution to the total GWP accounts for $95-98 \%$. Among the secondary gases, emissions mainly come from CO and $\mathrm{N}_{2} \mathrm{O}$. Regarding GWPs for $\mathrm{CH}_{4}$ and NMVOC emissions, a wide uncertainty range in GWPs was reported. The factors for these compounds include the impacts on tropospheric ozone, $\mathrm{CH}_{4}$ through changes in hydroxyl radicals $(\mathrm{OH})$ and $\mathrm{CO}_{2}$. The uncertainties are attributable to the short lifetimes of NMVOCs and the nonlinear chemistry involved in ozone and $\mathrm{OH}$ chemistry (Collins et al., 2002). However, due to the low contribution of such gases to the total emissions, no significant variation is expected when considering a change in GWPs. Indeed, an increase of $100 \%$ in NMVOCs GWP, which corresponds with the maximum 
uncertainty range reported by Collins et al. (2002), would mean less than $0.15 \%$ of change in the contribution of the other GHGs to the total GWP.

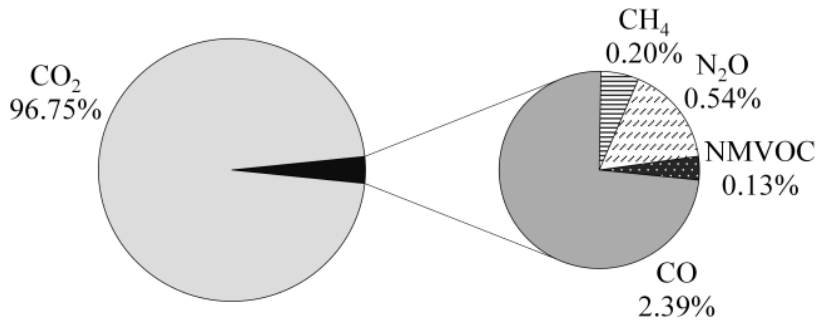

Figure 4. Average contribution of each gas to the total 100-year GWP

\subsection{Improvement potential of reduction scenarios}

Three alternative scenarios were proposed in order to assess the improvement actions proposed. Forestry activities, new technologies and speed dependency were evaluated through a sensitivity analysis. GHG reduction in the three cases was compared with a current scenario, which refers to the latest quantified emissions in 2010

Figure 5 illustrates the compensation potential of forests. According to Figure $5 \mathrm{a}$, a significant $\mathrm{GHG}$ reduction of about $10,000 \mathrm{t} \mathrm{CO}_{2}$ requires at least 100,000 exemplars. Considering a mean density of 1,100 trees/ha from Palahí et al. (2006), a total surface of 90.9 ha should be afforested. However, the effectiveness of the measure would strongly be dependent on the traffic density of the stretch. As shown in Figure 5b, the planting of 90.9 ha forest would be a successful measure to mitigate nearly $75 \%$ emissions of a low ADT stretch during one year of exploitation, whereas the same surface would suppose no more than $2.2 \%$ in a high ADT such as Barcelona-Tarragona. 
(a)

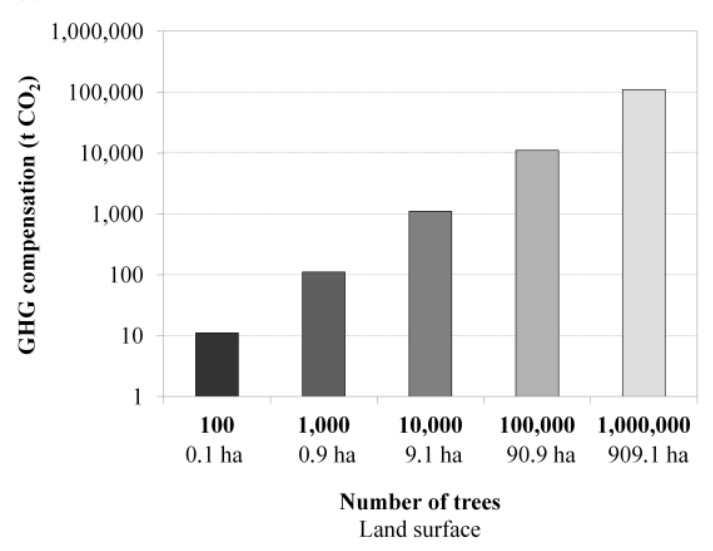

(b)

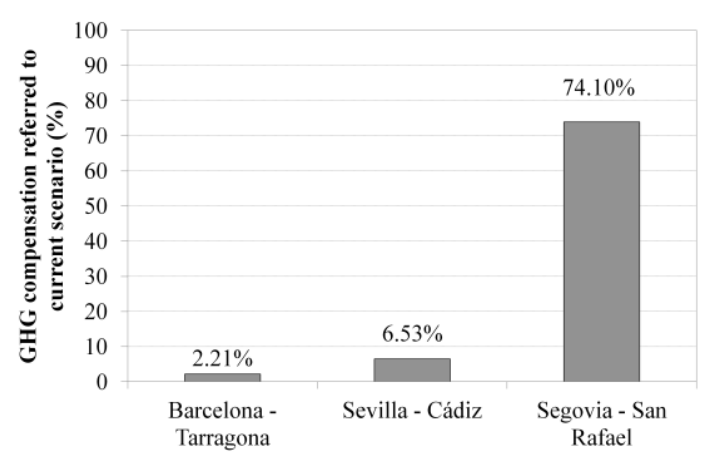

Figure 5. GHG compensation potential of forest species: tons of $\mathrm{CO}_{2}$ vs number of trees and land surface (a) and $\mathrm{CO}_{2}$ reduction percentage of 100,000 trees with respect to total GHG emissions per year (b)

The second scenario evaluates the substitution of vehicles by new technologies. This change will certainly affect the national road fleet in the near future, not only due to the encouragement measures of climate policies, but also as an inherent evolution of the vehicles. Nevertheless, the effect of the substitution is rather limited. A moderate variation, such as the substitution of light or heavy vehicles by Euro 5 technologies, allows less than $1 \%$ of average reduction that can rise to $1.6 \%$ if both measures are combined. Higher diminutions may be achieved by applying more drastic changes. In this sense, the substitution of all passenger cars with hybrid vehicles would mean an improvement of $10.3 \%$ with respect to the current emissions. However, this change will probably imply a substantial modification of the manufacturing processes that should be taken into account by extending the limits of the system.

The speed dependency of emissions is presented in Figure 6. An average speed scenario of $120 \mathrm{~km} / \mathrm{h}$ for light vehicles was considered as the baseline. According to the results, a decrease of speed of such vehicles from 120 to $115 \mathrm{~km} / \mathrm{h}(-4.2 \%)$ 
involves a global reduction of $4.4 \%$ emissions that can be improved until $8.2 \%$ when increasing the limitation to $110 \mathrm{~km} / \mathrm{h}(-8.3 \%)$. On the contrary, an equivalent raise in speed would entail a growth of $5.0 \%$ in GHG emissions for $125 \mathrm{~km} / \mathrm{h}$ and $10.8 \%$ in the case of $130 \mathrm{~km} / \mathrm{h}$. Therefore, GHG emissions clearly depend on speed following an exponential behavior.

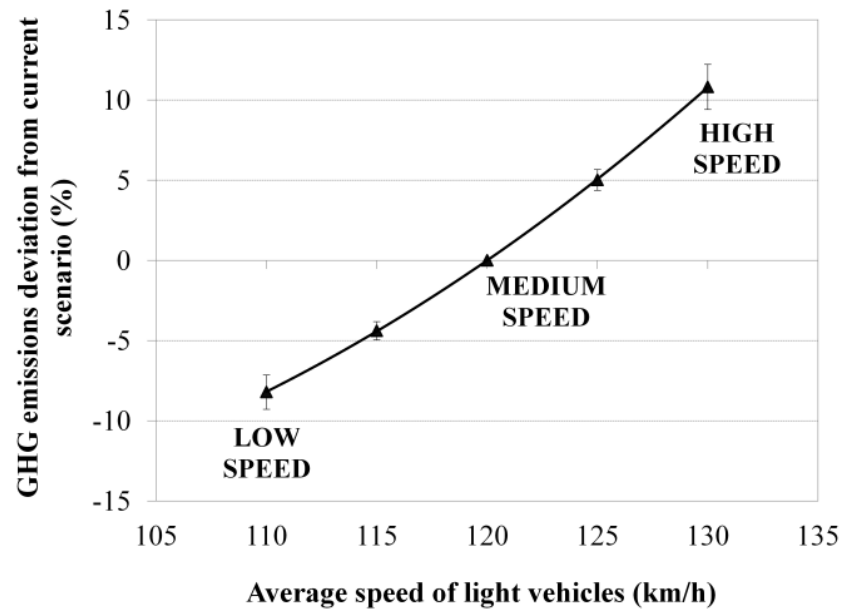

Figure 6. Average effect of speed of light vehicles on total GHG emissions

\section{Discussion}

\subsection{Conditioning factors of $\mathrm{GHG}$ emissions.}

The comparison between the selected model stretches allows observing that ADT is the most relevant factor affecting GHG emissions from motorway transport. This parameter directly settles the VKT that affects the fuel consumption calculated from eq 2 and consequently $\mathrm{CO}_{2}$ emissions. As $\mathrm{CO}_{2}$ contribution accounts for more than $96 \%$ of total emissions, any change in fuel consumption would involve a substantial alteration in the environmental impact of the road on global warming. The importance of VKT for the reduction of GHG emissions from transport has been widely reported in the literature (Boies et al., 2009; Melaina et al., 2011; Thambiran and Diab, 2011). The quantified emissions show, indeed, that the drop in VKT 
during the last three years of the analyzed period has turned into a significant reduction of GHG release. No mitigation policy related to VKT diminution has been proposed in Spain yet, but the improvement in fuel consumption has been pursued by reducing the speed limitation by $8 \%$.

Another factor that should be considered is the evolution of vehicles. The GHG emissions per $\mathrm{km}$ for the three model stretches decreased by 5\% in 2010 with respect to the values of 2005 . This tendency reflects the substitution of old vehicles by new technologies. As an example, new passenger cars in EU reduced their average emissions from 162.4 to $140.3 \mathrm{~g} \mathrm{CO}_{2} \mathrm{eq} / \mathrm{km}$ during the mentioned period (EEA, 2011), which implies a reduction of $13.6 \%$. The results observed in this research work show a significantly lower decrease, which can be due to the fact that new technologies only represent $4 \%$ of the total fleet for the last year, and passenger cars stand for nearly $78 \%$ of these new vehicles.

In addition, a relationship between the average capacity of the road fleet and unitary emissions was checked out. In this sense, emissions per $\mathrm{km}$ are function of the engine size and the weight of the vehicle (De Mol et al., 2009; EMEP/EEA Emission Inventory Guidebook, 2009; Zervas, 2010a; Zervas, 2010c). According to the results, the contribution of passenger cars to GHG emissions was strongly dependent on the engine capacity. For example, $\mathrm{CO}_{2}$ emissions from a gasoline passenger car with a 1.2 $\mathrm{L}$ engine are between $15-30 \%$ lower than those from a vehicle with $2.0 \mathrm{~L}$ engine of the same technology. In the case of fleet weight, stretches with large percentages of heavy vehicles actually emit higher levels of GHGs, as shown in Figure 3. Consequently, the reduction in unitary emissions observed from 2008 in Figure 2 can be partially attributed to the drop in ADT of heavy vehicles. 


\subsection{Influence of financial crisis}

The present study confirms the decrease of GHG emissions from transport since 2008 , coinciding with the start of the financial crisis. It has been already pointed out that the recession has brought a sharp drop in EU emissions, which supposed a 14\% reduction compared to 1990 levels (European Commission, 2010; OECD/ITF, 2010). Our results show slightly more moderate global diminutions, by $5-9 \%$ annually during the period 2007-2010, except from the low ADT stretch, that revealed a yearly increase of $3 \%$ from 2008 to 2010 . The reduction has especially affected the sector of road freight transport due to the decline in European trade volume (OECD/ITF, 2009; Pasi, 2009). In the considered model stretches, the lowest percentage of heavy vehicles was found in 2010, with $14-31 \%$ fewer vehicles from this category than in 2005. Nevertheless, despite current projections for the next years predict lower GHG levels than expected before the crisis, several authors maintain that the decrease has been rather limited and emissions will rapidly grow after this period, partly due to emerging economies (Enkvist et al., 2010; OECD/ITF, 2011; Peters et al., 2012).

\subsection{Effectiveness of mitigation measures}

The sensitivity analysis for the three mitigation scenarios demonstrates the limitations of individual measures to overcome climate change. Firstly, carbon offset projects, which include afforestation and reforestation activities as temporary credits, are gaining interest in the business field, not only to accomplish future legislation but also as a marketing tool or an indicator of social corporate responsibility (FAO, 2010). Nevertheless, a relevant GHG mitigation based on this strategy would require a large number of tree exemplars and hence, a vast land surface. In the present study, 
afforestation is proposed as a direct measure from the motorway operator. According to this perspective, the outcomes of the assessment allow concluding that the success of forestry activities for transport mitigation is restricted to low ADT stretches with moderate level of emissions.

The second measure of encouraging vehicle substitution is not a significant option unless it brings a radical change in the road fleet. However, the number of new passenger car registrations tends to decrease in EU countries during the last years, as the markets of the countries become more saturated (Zervas, 2010b). Therefore, a radical change would require an integration of international policies, affecting worldwide car manufacturers. Nevertheless, according to the estimated emissions, the development of the latest regulation has a relatively slight effect in the total emissions and a noticeable reduction would require the generalized adoption of new technologies such as hybrid models instead of fossil fuel vehicles. As a result, technological improvement policies, such as vehicle taxes dependent on environmental criteria or subsidizing new vehicles (West, 2004), have a limited repercussion in the near future, though the quantitative potential of drastic changes make them more interesting in a long-term perspective.

Reduced speed limits have been widely proposed as an effective method for GHG diminution (André and Hammarström, 2000; Barkenbus, 2010; Michaelis and Davidson, 1996; Winkelman et al., 2003). Moreover, changes in speed limits according to different types of roads are currently being discussed within the Spanish context. According to Greener (2008), for each $5 \mathrm{mph}(8 \mathrm{~km} / \mathrm{h})$ above $55 \mathrm{mph}(88$ $\mathrm{km} / \mathrm{h}$ ), fuel economy decreases by approximately $7 \%$. As $\mathrm{CO}_{2}$ directly depends on fuel consumption and it is the main contributor to total emissions, this behavior involves an equivalent drop in GHG release. Comparable GHG reductions ranging 
from 4 to $8 \%$ have been found in the present study for a diminution of 5 and $10 \mathrm{~km} / \mathrm{h}$ respectively. As a result, speed limitation seems the most direct measure of the analyzed scenarios.

\section{Conclusions}

Nowadays, road transport plays a significant role in worldwide GHG emissions, as well as within the Spanish context. Particularly, highways and motorways represent an important percentage of the total trips and thus a large amount of emissions come from these types of road. The aim of this study was to analyze the main factors that condition the GHG emissions in Spanish motorways and evaluate feasible measures in order to limit global warming.

GHG emissions from three model stretches during the period 2005-2010 were quantified by applying the Tier 3 methodology. According to the results, average daily traffic (ADT) was found to be the most significant parameter, although the average fleet age and vehicle size also affected the environmental impacts. In addition, there was a clear connection between the reduction in European trade volume during the financial crisis and the GHG release, despite its temporary effect. Subsequently, three improvement scenarios were evaluated. The first one consisted of the compensation of GHG emissions through afforestation activities. Despite the limitation due to the surface requirements, this is the only measure that can be implemented by the company itself. Following this perspective, its effectiveness is restricted to those stretches with a low ADT, although the potential of the alternative may increase if involving a national mitigation policy.

Regarding the technological improvement scenario, the substitution of vehicles is a slow process and the GHG emission reductions seem rather narrow unless an 
international drastic change is encouraged. Policies focused in the substitution of fossil fuel vehicles by more efficient technologies such as hybrid vehicles would strengthen the potential of this option. Thus, the interest of the measure is limited to a long-term perspective.

Reduced speed scenario allows a substantial improvement with a minimal change in both fleet and road conditions. Therefore, reinforcement of speed limits proved to be the most appealing alternative in the near future. Nevertheless, a combination of measures would involve a more robust strategy that will certainly allow achieving higher GHG emission reductions.

Acknowledgements This work has been developed within the framework of a research project financed by the Abertis Foundation (Research Contract 2010/CL561). P. Pérez-López would like to express her gratitude to the Spanish Ministry of Education for awarding a research scholarship (FPU12/01605).

\section{References}

André, M., Hammarström, U., 2000. Driving speeds in Europe for pollutant emissions estimation. Transportation Research Part D - Transport and Environment 5(5), 321-335.

Baiocchi, G., Minx, J.C., 2010. Understanding changes in the UK's $\mathrm{CO}_{2}$ emissions: A Global Perspective. Environmental Science \& Technology 44(4), 1177-1184.

Bala, G., Caldeira, K., Wickett, M., Phillips, T.J., Lobell, D.B., Delire, C., Mirin, A., 2007. Combined climate and carbon-cycle effects of large-scale deforestation. Proceedings of the National Academy of Science of the United States of America 104(16), 6550-6555.

Barkenbus, J.N., 2010. Eco-driving: An overlooked climate change initiative. Energy Policy 38(2), 762-769.

Barth, M., Boriboonsomsin, K., 2008. Real-world carbon dioxide impacts of traffic congestion. Transportation Research Record 2058, 163-171. 
Betts, R.A., 2000. Offset of the potential carbon sink from boreal forestation by decreases in surface albedo. Nature 408, 187-190.

Boies, A., Hankey, S., Kittelson, D., Marshall, J.D., Nussbaum, P., Watts, W., Wilson, E.J., 2009. Reducing motor vehicle greenhouse gas emissions in a non-California state: a case study of Minnesota. Environmental Science \& Technology 43(23), 8721-8729.

Brown, S., 1997. Estimating biomass and biomass change of tropical forests: a Primer. FAO Forestry Paper: Rome; pp 5-10.

Burriel, J.A., Gracia, C., Ibàñez, J.J., Mata, T., Vayreda, J., 2004. Inventari Ecològic i Forestal de Catalunya. Mètodes. CREAF, Bellaterra: Cerdanyola del Vallès, Vol. 9.

Canadell, J.G., Raupach, R., 2008. Managing forests for climate change mitigation. Science 320(5882), 273-277.

Chester, M.V., Horvath, A., 2009. Environmental assessment of passenger transportation should include infrastructure and supply chains. Environmental Research Letters 4, 024008.

Collins, W.J., Derwent, R.G., Johnson, C.E., Stevenson, D.S., 2002. The oxidation of organic compounds in the troposphere and their global warming potentials. Climatic Change 52(4), 453479 .

Creutzig, F., McGlynn, E., Minx, J., Edenhofer, O., 2011. Climate policies for road transport revisited (I): Evaluation of the current framework. Energy Policy 39(5), 2396-2406.

Crowley, T.J., 2000. Causes of climate change over the past 1000 years. Science 289, 270-277.

Davis, S.C., Diegel, S.W., Boundy, R.G., 2010. Transportation Energy Data Book: Edition 29, ORNL6985, Oak Rige National Laboratory, Oak Ridge,Tennessee.

De Mol, J., Vlassenroot, S., Zwerts, E., Allaert, G., Witlox, F., 2009. In The evolution of car power, weight and top speed during the last twenty years in Belgium : a consideration for future policies, Proceedings of the BIVEC-GIBET Transport Research Day; Macharis C, Turcksin L, Eds. VUB Press; pp 607-620.

De Vries, W., Reinds, G.J., Gundersen, P., Sterba, H., 2006. The impact of nitrogen deposition on carbon sequestration in European forests and forest soils. Global Change Biology 12(7), 11511173.

Doney, S.C., Lindsay, K., Fung, I., John, J., 2006. Natural variability in a stable, 1000-Yr global coupled climate - carbon cycle simulation. Journal of Climate, 19, 3033-3054. 
EEA., 2011. Greenhouse gas emissions in Europe: a retrospective trend analysis for the period 19902008; Report 6/2011; European Environment Agency: Copenhagen. Available online at: http://eea.europa.eu (accessed November 23, 2011).

EEA, 2010. Monitoring the $\mathrm{CO}_{2}$ emissions from new passenger cars in the EU: summary of data for 2010; European Environment Agency. Available online at: http://eea.europa.eu (accessed June 12, 2012).

El-Shawarby, I., Ahn, K., Rakha, H., 2005. Comparative field evaluation of vehicle cruise speed and acceleration level impacts on hot stabilized emissions. Transportation Research Part D - Transport and Environment 10(1), 13-30.

EMEP/EEA air pollutant emission inventory guidebook - 2009. Technical report No. 9/2009; European Environment Agency: Copenhagen. Available online at: http://www.eea.europa.eu/ (accessed June 11, 2012).

Enkvist, P.A., Dinkel, J., Lin, C., 2010. Impact of the financial crisis on carbon economics: version 2.1 of the global greenhouse gas abatement cost curve. McKinsey \& Company.

EPA, 2009. Light-Duty Automotive Technology, Carbon Dioxide Emissions, and Fuel Economy Trends: 1975 Through 2009; United States Environmental Protection Agency. Available online at: http://www.epa.gov/otaq/cert/mpg/fetrends/fetrends-archive.htm (accessed June 12, 2012).

European Commission, 2008. Commission staff working document accompanying document to the proposal for a Directive of the European Parliament and of the Council amending Directive 2003/87/EC so as to improve and extend the EU greenhouse gas emission allowance trading system. Impact assessment; SEC (2008) 52; European Commission: Brussels. Available online at: http://ec.europa.eu/index_en.htm (accessed June 6, 2012).

European Commission, 2010. Communication from the Commission to the European Parliament, the Council, the European Economic and Social Committee and the Committee of the Regions Analysis of options to move beyond $20 \%$ greenhouse gas emission reductions and assessing the risk of carbon leakage SEC(2010) 650; European Commission: Brussels. Available online at: http://ec.europa.eu/index_en.htm (accessed June 13, 2012).

FAO, 2010. Agriculture, forestry and other land use mitigation project database; Mitigation of Climate Change in Agriculture (MICCA) Project. Series 2; Food and Agriculture Organization of the 
United Nations. Available online at: http://www.fao.org/climatechange/publications/en/ (accessed June 13, 2012).

Forster, P., Ramaswamy, V., Artaxo, P., Berntsen, T., Betts, R., Fahey, D.W., Haywood, J., Lean, J., Lowe, D.C., Myhre, G., Nganga, J., Prinn, R., Raga, G., Schulz, M., Van Dorland, R., 2007. Changes in atmospheric constituents and in radiative forcing. In Climate Change 2007: The Physical Science Basis. Contribution of Working Group I to the Fourth Assessment Report of the Intergovernmental Panel on Climate Change, Solomon S, Qin D, etc., Eds. Cambridge University Press: Cambridge and New York. Available online at: http://www.ipcc.ch/ (accessed June 12, 2012).

Fuglestvedt, J., Berntsen, T., Myhre, G., Rypdal, K., Skeie, R.B., 2008. Climate forcing from the transport sectors. Proceedings of the National Academy of Science of the United States of America 105(2), 454-458.

García, M.A., Sánchez, M.L., Pérez, I.A., 2010. Synoptic weather patterns associated with carbon dioxide levels in northern Spain. Science of the Total Environment 408(16), 3411-3417.

González-García, S., Gasol, C.M., Gabarrell, X., Rieradevall, J., Moreira, M.T., Feijoo, G., 2010. Environmental profile of ethanol from poplar biomass as transport fuel in Southern Europe. Renewable Energy 35(5), 1014-1023.

Greener, D., 2008. Near term options to increase fuel economy and decrease petroleum demand. Testimony to the US Senate Committee on Energy and Natural Resources, July 23.

Guinée, J.B., Gorreé, M., Heijungs, R., Huppes, G., Kleijn, R., De Koning, A., Van Oers, L.A., Wegener Seeswijk, A., Suh, S., Udo de Haes, H.A., De Bruijn, H., Van Duin, R., Huijbregts, M., 2011. Life Cycle Assessment: An Operational Guide to the ISO Standards. Leiden.

Hansen, J.Q., Winther, M., Sorenson, S.C., 1995. The influence of driving patterns on petrol passenger car emissions. Science of the Total Environment 169(1), 129-139.

IEA, 2011. World Energy Outlook 2011. OECD/IEA: Paris; pp 69-99.

IPCC, 2003. Good Practice Guidance for Land Use, Land Use Change and Forestry; IPCC: Hayama. Available online at: http://www.ipcc.ch/ (accessed June 5, 2012).

IPCC, 2007. Climate Change 2007: Synthesis report. Contribution of Working Groups I, II and III to the Fourth Assessment Report of the Intergovernmental Panel on Climate Change. [Core Writing 
Team, Pachauri, R.K and Reisinger, A. (eds.)]. IPCC: Geneva. Available online at: http://www.ipcc.ch/ (accessed November 21, 2011).

Kaul, M., Mohren, G.M.J., Dadhwal, V.K., 2010. Carbon storage versus fossil fuel substitution: a climate change mitigation option for two different land use categories based on short and long rotation forestry in India. Mitigation and Adaptation Strategies for Global Change 15(4), 395-409.

Li, J., 2011. Decoupling urban transport from GHG emissions in Indian cities - A critical review and perspectives. Energy Policy 39(6), 3503-3514.

Lindner, M., Maroschek, M., Netherer, S., Kremer, A., Barbati, A., Garcia-Gonzalo, J., Seidl, R., Delzon, S., Corona, P., Kolström, M., Lexer, M.J., Marchetti, M., 2010. Climate change impacts, adaptive capacity and vulnerability of European forest ecosystems. Forest Ecology and Management 259(4), 698-709.

Malhi, Y., Meir, P., Brown, S., 2002. Forest, carbon and global climate. Philosophical Transactions of the Royal Society A: Mathematical Physical and Engineering Sciences 360, 1567-1591.

Malmsheimer, R.W., Heffernan, P., Brink, S., Crandall, D., Deneke, F., Galik, C., Gee, E., Helms, J.A., McClure, N., Mortimer, M., Ruddell, S., Smith, M., Stewart, J., 2008. Forest Management Solutions for Mitigating Climate Change in the United States. Journal of Forestry 106(3), 115-173.

Marland, G., Schlamadinger, B., 1997. Forests for carbon sequestration or fossil fuel substitution? A sensitivity analysis. Biomass and Bioenergy 13(6), 389-397.

Marshall JD, McKone TE, Deakin E, Nazaroff WW. Inhalation of motor vehicle emissions: effects of urban population and land area. Atmos Environ 2005; 39(2):283-95.

McCarl, B.A., Sands, R.D., 2007. Competitiveness of terrestrial greenhouse gas offsets: are they a bridge to the future? Climatic Change 80(1-2), 109-126.

Meinshausen, M., Meinshausen, N., Hare, W., Raper, S.C.B., Frieler, K., Knutti, R., Frame, D.J., Allen, M.R., 2009. Greenhouse-gas emission targets for limiting global warming to $2^{\circ} \mathrm{C}$. Nature 458, 1158-1162.

Melaina, M., Webster, K., 2011. Role of fuel carbon intensity in achieving 2050 greenhouse gas reduction goals within the light-duty vehicle sector. Environmental Science \& Technology 45(9), 3865-3871.

Michaelis, L., Davidson, O., 1996. GHG mitigation in the transport sector. Energy Policy 24(10-11), 969-984. 
Nguyen, T.L.T., Gheewala, S.H., Garivait, S., 2007. Fossil energy savings and GHG mitigation potentials of ethanol as a gasoline substitute in Thailand. Energy Policy 35(10), 5195-5205.

Ntziachristos, L., Samaras, Z., 2000. Speed dependent representative emission factors for catalyst passenger cars and influencing parameters. Atmospheric Environment 34(27), 4611-4619.

OECD/ITF, 2009. Transport Outlook 2009: Globalisation, Crisis and Transport; International Transport Forum. Available online at: http://www.internationaltransportforum.org/jtrc/DiscussionPapers/jtrcpapers.html (accessed June 13, 2012).

OECD/ITF, 2010. Reducing transport Greenhouse Gas Emissions. Trends and Data 2010; International Transport Forum. Available online at: http://www.internationaltransportforum.org/Pub/resreports.html (accessed June 12, 2012).

OECD/ITF, 2011. Transport Outlook 2011: Meeting the Needs of 9 Billion People; International Transport Forum. Available online at: http://www.internationaltransportforum.org/Pub/TranspOutlook.html (accessed June 6, 2012).

Palahí, M., Pukkala, T., Trasobares, A., 2006. Calibrating predicted tree diameter distributions in Catalonia, Spain. Silva Fennica 40(3), 487-500.

Pandian, S., Gokhale, S., Ghoshal, A.K., 2009. Evaluating effects of traffic and vehicle characteristics on vehicular emissions near traffic intersections. Transportation Research Part D - Transport and Environment 14(3), 180-196.

Pasi, S., 2009. Global economic crisis hits European road freight transport in the fourth quarter of 2008; Statistics in Focus 86/2009; Eurostat: Luxembourg. Available online at: http://epp.eurostat.ec.europa.eu/portal/page/portal/eurostat/home (accessed June 12, 2012).

Pérez-Cruzado, C., Mansilla-Salinero, P., Rodríguez-Soalleiro, R., Merino, A., 2012. Influence of tree species on carbon sequestration in a humid temperate region. Plant and Soil 353 (1-2), 333-353.

Peters, G.P., Marland, G., Le Quere, C., Boden, T., Canadell, J.G., Raupach, M.R., 2012. Rapid growth in $\mathrm{CO}_{2}$ emissions after the 2008-2009 global financial crisis. Nature Climate Change 2(1), 2-4.

Richter, D.D., Markewitz, D., Trumbore, S.E., Wells, C.G., 1999. Rapid accumulation and turnover of soil carbon in a re-establishing forest. Nature 400, 56-58.

SIBosC. MiraBosc on-line, consultes on-line de l'Inventari Ecològic i Forestal de Catalunya. CREAF/DMAH. Available online at: http://natura.uab.es/mirabosc/ (accessed June 13, 2012). 
Sjodin, A., Persson, K., Andreasson, K., Arlander, B., Galle, B., 1998. On-road emission factors derived from measurements in a traffic tunnel. International Journal of Vehicle Design 20(1-4), 147-158.

Smith, P., 2004. Carbon sequestration in croplands: the potential in Europe and the global context. European Journal of Agronomy 20(3), 229-236.

Spanish General Directorate of Traffic (DGT). Ministry of Interior. Government of Spain. Available online at: http://www.dgt.es/portal/es/seguridad_vial/estadistica/ (accessed June 12, 2012).

Spanish Ministry of Development. Government of Spain. Available online at: http://www.fomento.gob.es/mfom/lang_castellano/ (accessed June 5, 2012).

Spanish Ministry of Development. Spanish Strategy for Sustainable Mobility. Government of Spain: Madrid, 2009. Available online at: http://www.fomento.gob.es/MFOM/LANG_CASTELLANO/_ESPECIALES/CALIDADAMBIE NTAL/ (accessed June 11, 2012).

Spanish Ministry of the Environment and Rural and Marine Affairs. Summary of the National Inventory of GHG Emissions: series 1990-2009. Government of Spain: Madrid, 2011. Available online at: http://www.magrama.gob.es/es/calidad-y-evaluacion-ambiental/temas/sistema-espanolde-inventario-sei-/ (accessed June 11, 2012).

Spanish Observatory for Sustainability (OSE). Manual de cálculo y reducción de huella de carbon para actividades de transporte por carretera. OSE: Madrid, 2011. Available online at: http://www.sostenibilidad-es.org/index.php (accessed June 11, 2012).

Spielmann, M., Bauer, C., Dones, R., Tuchschmid, M., 2007. Transport Services. Ecoinvent report No. 14. Swiss Centre for Life Cycle Inventories, Dübendorf, Switzerland.

Stephens-Romero, S., Carreras-Sospedra, M., Brouwer, J., Dabdub, D., Samuelsen, S., 2009. Determining air quality and greenhouse gas impacts of hydrogen infrastructure and fuel cell vehicles. Environmental Science \& Technology 43(23), 9022-9029.

Streck, C., Tuerk, A., Schlamadinger, B., 2009. Foresty offsets in emissions trading systems: a link between systems? Mitigation and Adaptation Strategies for Global Change 14(5), 455-463.

Tan, K.T., Lee, K.T., Mohamed, A.R., 2008. Role of energy policy in renewable energy accomplishment: The case of second-generation bioethanol. Energy Policy 36(9), 3360-3365. 
Thambiran, T., Diab, R.D., 2011. Air pollution and climate change co-benefit opportunities in the road transportation sector in Durban, South Africa. Atmospheric Environment 45(16), 2683-2689.

UK Government. Directgov: Calculate your car's tax and $\mathrm{CO}_{2}$ emissions. Available online at: http://www.direct.gov.uk/en/Diol1/DoItOnline/DG_10015994 (accessed June 12, 2012).

UK Government. Van $\mathrm{CO}_{2}$ and Fuel Consumption Database. Available online at: http://vanfueldata.dft.gov.uk/Default.aspx (accessed June 12, 2012).

UNFCCC, 1998. Kyoto Protocol to the United Nations Framework Convention on Climate Change. In Report of the Conference of the Parties on its third session held at Kyoto from 1 to 11 December 1997. Addendum. Part Two: Action taken by the Conference of the Parties at its third session, Decision 1/CP.3, Annex (FCCC/CP/1997/L7/Add.1). UNFCCC: Bonn. Available online at: http://unfccc.int/kyoto_protocol/items/2830.php (accessed June 11, 2012).

Walther, G.R., Post, E., Convey, P., Menzel, A., Parmesan, C., Beebee, T.J.C., Fromentin, J.M., Hoegh-Guldberg, O., Bairlein, F., 2002. Ecological responses to recent climate change. Nature 416, 389-395.

Weigel, B.A., Southworth, F., Meyer, M.D., 2010. Calculators to Estimate Greenhouse Gas Emissions from Public Transit Vehicles. Transportation Research Record 2143, 125-133.

West, S.E., 2004. Distributional effects of alternative vehicle pollution control policies. Journal of Public Economics 88(3-4), 735-757.

Winkelman, S., Dierkers, G., 2003. Reducing the Impacts of Transportation on Global Warming: Summary of New York Greenhouse Gas Task Force Recommendations. Transportation Research Record 1842, 83-90.

Zervas, E., 2010a. Analysis of the $\mathrm{CO}_{2}$ emissions and of the other characteristics of the European market of new passenger cars. 2. Segment analysis. Energy Policy 38(10), 5426-5441.

Zervas, E., 2010b. Analysis of the $\mathrm{CO}_{2}$ emissions and of the other characteristics of the European market of new passenger cars. 1. Analysis of the general data and analysis per country. Energy Policy 38(10), 5413-5425.

Zervas, E., 2010c. Analysis of the $\mathrm{CO}_{2}$ emissions and of the other characteristics of the European market of new passenger cars. 2. Brands analysis. Energy Policy 38(10), 5442-5456. 